\title{
PERFORMANCE DIVERGENCE AND FINANCIAL DISTRESS OF SELECTED STEEL COMPANIES IN INDIA
}

\section{S.RANJITHKUMAR}

Assistant Professor, Department of Management and Commerce, Amrita University, Mysore, Karnataka, India

\section{ABSTRACT}

There is a surge in the Steel industry, due to cyclical economic factors like the slowdown in economic growth, along with its structural challenges, which refers to excess capacity in its production. At the outset, the contribution of the steel industry to GDP is about 7\%, which almost ranked next to China, in world context. But, these rates are an average (3.3\%) to the world's GDP rate. In spite of the growth favor to the Indian Steel sector, there is a boomerang to the steel sector of tax policy. GST was not increased by any customs duty for finished products, but, raw materials are attracting import duty of $2.5 \%$. Firstly, it is to be subdued, very soon. A comparative growth of other core sectors is also the prime influencing factor, for simultaneous growth of steel sector. Emerging markets are also very less for steel industry. Growth prospects are more favorable to Indian Steel industry; still there is a need of reform changes with global perspectives. Competition persists always, between existing companies. There will be a less probability of new emerge of steel company, as its investment is too high. This paper highlights the possibilities of industrial sickness, among selected steel industries, in India.

KEYWORDS: Core Sector, GDP, Emerged Markets \& Structural Challenges

Received: Sep 12, 2017, Accepted: Sep 30, 2017, Published: Oct 13, 2017, Paper Id: IJMPERDOCT201739

\section{STEEL INDUSTRY - AN OVERVIEW}

Steel is crucial to the development of any modern economy and is considered to be the backbone of human civilization. The level of per capital consumption of steel is treated as an important index, of the level of socioeconomic development and living standards of the people, in any country. It is a product of large and technologically complex industry, having strong forward and backward linkages, in terms of material flows and income generation. All major industrial economies are characterized by the existence of a strong steel industry. The growth of many of these economies has been largely shaped by the strength of their steel industries, in their initial stages of development. The steel industry was in the vanguard, during the liberalization of the industrial sector and has made rapid strides, since then. The new Greenfield plant represents the latest in technology, due to which, output has increased; the industry has moved up in the value chain and the exports have raised consequent to a greater integration, with the global economy. The new plants have also brought about a greater regional dispersion, easing the domestic supply position, notably in the western region. At the same time, the domestic steel industry faces new challenges. Some are related to the trade barriers in the developed markets and certain structural problems of the domestic industry are notably, due to the high cost of commissioning of new projects. The litmus test of the steel industry will be to surmount these difficulties and remain globally competitive.

Steel has been the key material, with which the world has reached to a developed position. All the 
engineering machines, mechanical tools and most importantly building and construction structures like bars, rods, channels, and wires are made of steel, for its feature being hard and adaptable. Earlier, when the alloy of steel was not discovered, iron was used for the said purposes but iron is usually prone to rust and is not so strong. Steel is a highly wanted alloy, over the world. All the countries need steel for the infrastructural development and overall growth. Steel has a variety of grades i.e. above 2000 but is mainly categorized into divisions - steel flat includes steel products in flat, plate, sheet or strip shapes. The plate shaped steel products are usually 10 to $200 \mathrm{~mm}$ and thin rolled strip products are about 1 to $10 \mathrm{~mm}$ in dimension. Steel flat is mostly used in construction, ship building, pipes and boiler applications. The steel long category includes steel products in long, bar or rod shape like reinforced rods made of sponge iron. The steel long products are required to produce concrete, blocks, bars, tools, gears and engineering products. After independence, successive governments placed great emphasis on the development of an Indian steel industry. In financial year 1991, the six major plants, of which five were in the public sector, produced 10 million tons. The rest of India's Steel production, 4.7 million tons, came from 180 small plants, almost all of which were in the private sector. India's Steel production more than doubled during the 1980s but still did not meet the demand in the mid - 1990s. The government was seeking private sector investment in new steel plants. Production was projected to increase substantially, As a result, plants set up a 1 million ton steel plant and three pig-iron plants totaling 6000,000 tons capacity in West Bengal, with Chinese technical assistance and financial investment. The commissioning of Tata Iron \& Steel Company's production unit in Jamshedpur, Bihar in 1911-12 heralded the beginning of the modern steel industry in India. At the time of Independence and the commencement of five year plans, the Government of India decided to set up four integrated steel plants at Rourkela, Durgapur, Bhilai and Bokaro. The Bokaro plant was commissioned in 1972. The most recent addition is a 3 Mt integrated steel plant with modern technology in Visakhapatnam. Steel Authority of India (SAIL), accounts for over 40 percent of India's, crude steel production. SAIL comprises of nine plants, including five integrated and four special steel plants. Of these, one was nationalized and two were acquired, several were set up in collaboration with foreign companies. SAIL also owns mines and subsidiary companies.

\section{OBJECTIVES OF THE STUDY}

To identify the steel companies, if any, that is in financial distress.

\section{SCOPE OF THE STUDY}

The study aims to make an analysis of the financial performance and growth of steel industry in India. The scope of financial performance is very wide and broad based. Hence, the study has analyzed the financial distress. Only those listed companies whose main product of manufacture are steel has been considered for the study. The companies which

have been merged are considered a single unit, for the purpose of the analysis. The external factors of financial performance are not considered in the study.

\section{HYPOTHESIS}

All profitable firms are free from financial distress

\section{RESEARCH METHODOLOGY}

\section{Sources of Data}

The present study is primarily based on secondary data comprising the financial statements of selected steel firms 
in India. The data has been collected from annual reports, journals, periodicals, publications, reports of the steel industry and websites. The data are secondary in nature. The data have been collected from the official directory and data base of the Centre for Monitoring Indian Economy (CMIE), namely PROWESS 3.5 version.

\section{Sampling Design}

To select the companies, purposive sampling technique has been adopted. The purposive sampling technique is an appropriate technique when information from every steel firm in the sample population is not valuable. The data base of CMIE has made a compilation for 90 companies (both, large and small), of which 37 companies have financial data available for a continuous period of 15 years, namely, 1996 - 2000 to 2001 - 2012. Such companies have been selected for the study. The companies for which data have not been available for one and more than one year between or at the beginning or at the end of study period have been ignored. Thus 37 companies from the Indian steel sector constitute the sample for the study.

\section{Classification of the Sample Companies}

Indian Steel industry belongs to 'core sector' which requires a heavy investment in assets. Hence, total assets of the firms have been considered as the basis for the classification of firms into 'small', 'medium' and 'large' size groups.

Table 1: Classification of Companies Based on the Value of the Total Assets

\begin{tabular}{|l|c|c|}
\hline \multicolumn{1}{|c|}{ Size } & Number of Companies & Percentage to Total \\
\hline Small & 11 & 29.7 \\
Medium & 15 & 40.6 \\
Large & 11 & 29.7 \\
\hline Total & 37 & 100 \\
\hline
\end{tabular}

\section{Area of Study}

The study is pertaining to the Indian steel industry.

\section{FRAME WORK OF ANALYSIS}

To analyze the financial performance of the selected firms in the Indian steel sector, Edward. I. Altman's Bankruptcy models have been applied, using SPSS version 17.

\section{SIGNIFICANCE OF THE STUDY}

The result of the study may be useful to the management to take investment decisions and anticipate future conditions, identification of its areas of strength and weakness, and to take appropriate decisions for the maximization of its intrinsic value. The study will help the policy makers in the evaluation of the performance of the steel industry. The study may also be useful to creditors in their effective credit policy decisions. The study will act as a guide to investors in their investment decisions the common public will also benefit from the fruitful information provided by the study.

The study has academic and practical significance. It helps the academicians and researchers to develop new ideas for future study. The study focuses on the performance of the steel industry, which may interest not only those who are interested in manufacturing steel or related products, but also others to see the process of change within the industry. 


\section{LIMITATIONS OF THE STUDY}

The financial statements from which data have been extracted are historical and quantitative without considering the impact of inflation in the accounting data. Hence, the study has incorporated all the limitations inherent in such statements. The effect of inflation has not been considered in the present study. Only 37 firms are selected for the study, remaining steel firms in the Indian steel industry has been excluded. The study has considered only internal factors for analysis

\section{REVIEW OF LITERATURE}

It is mandatory to review the literature available with respect to the area of the research study. Measuring the financial performance of the corporate sector has always been an area of controversies, from the point of view of the government, shareholders, prospective investors, creditors, employees and other stakeholders. Several studies have been undertaken, to analyze the financial performance in the corporate sector. This chapter presents a brief review of the important studies conducted by financial analysts in the area financial distress.

George Gallinger $(2000)^{26}$, has made a study on 'Prediction of Financial Distress', as the fifth part of the framework for financial statement analysis. He has used Number Cruncher mode of Kaplan and Urwitz that predicts the bond rating of a company, Z-score model by Edward I Altman and Lambda model by Gary Emery to test the solvency of the company in his study. The bond rating model is dependent on the firm's size, long-term debt to total assets ratio, net income to sales, variability in the net income as measured by its coefficient of variation, and interest coverage ratio. Altman's Z-score Bankruptcy prediction model has been based on EBIT/Total assets, Net working capital to total assets, Market value of Equity to book value of debt, retained earnings to total assets and sales to total assets. Applying this model, he has identified whether the firm chosen for the study was under 'grey' area or 'no threat' area.

Rajesh. M and Ramana Reddy N.R.V (2010) ${ }^{46}$, in their study, "An Empirical Study on Financial Distress", have analyzed the financial performance of Chittoor Co-operative Sugars Ltd, A.P. An Agra based company through liquidity, working capital investment efficiency and solvency ratios. The study period was from 2003-2008. The Z-score has shown a bad financial performance leading to bankruptcy. The results of the analysis have indicated that the liquidity, working capital turnover efficiency and solvency position of the company are not good.

Mr. H. Chandra and V. Selvaraj $(2013)^{50}$, have analyzed the financial health of the selected steel companies in India. In this study out of 118 companies quoted in the Bombay stock exchange list, 38 steel companies have been selected for a period of 2000-01 to 2009-10. The data has been collected from Prowess database. The Researchers have used Altman's Z score model for the study. The study has shown that it is clear that the financial health of small size, steel companies is not satisfied during the study period. Medium and large size, steel companies have been in distress zone with an average over the period.

P. Rajangam and V. Selvaraj (2013) ${ }^{52}$, have attempted to study the financial health of West Coast Paper Mill Limited. The study covers a period a twelve financial year from 2000-01 to 2011-12. The research is fully based upon the secondary data, which has been collected from the official directory of Bombay stock exchange, Capitoline plus corporate data base. To evaluate the financial health of a company, the authors have used Altman's Z score model in addition to mean, standard deviation, co-efficient of variation and t-distribution. The study has concluded that the company's overall financial health has been satisfactory during the research period. 
Sarbapriya Ray $(2013)^{53}$, has examined the financial soundness of the Indian manufacturing industry, for a study period of 7 years, from 2003-04 and 2009-10. The study is based on secondary data. The data have been collected from the published source, namely, CMIE Prowess database, pertaining to 5,392 publicly traded companies. She has applied Altman's Z score model, Multi Discriminant analysis and financial ratios, to analyze the data. The study has concluded that the overall financial performances of the manufacturing sector in India at present are viable as Z score indicates but it may lead to corporate bankruptcy in near future unless regulatory measures are undertaken immediately.

Sivakumar $(2013)^{54}$, has studied the financial efficiency of steel industry in India. The data has been for a period of 10 years, from 1997 - 98 to 2006 -07. Mean, standard deviation, regression analysis and coefficient of variation have been applied in this study. The study has shown that the financial viability of the industry becomes essential to understand the strength of the steel industry in the given competitive situation.

Steel has been the key material with which the world has reached to a developer position. All the engineering machines, mechanical tools and most importantly building and construction structures like bars, rods, channels, and wires are made of steel for its feature being hard and adaptable. Earlier, when the alloy of steel was not discovered, iron was used for the said purposes but iron is usually prone to rust and is not so strong. Steel is a highly wanted alloy over the world. All the countries need steel for the infrastructural development and overall growth. Steel has a variety of grades i.e. above 2000 but is mainly categorized into divisions - steel flat includes steel products in flat, plate, sheet or strip shapes. The plate shaped steel products are usually 10 to $200 \mathrm{~mm}$ and thin rolled strip products are about 1 to $10 \mathrm{~mm}$ in dimension. Steel flat is mostly used in construction, ship building, pipes and boiler applications. The steel long category includes steel products in long, bar or rod shape like reinforced rods made of sponge iron. The steel long products are required to produce concrete, blocks, bars, tools, gears and engineering products. After independence, successive governments placed great emphasis on the development of an Indian steel industry. In financial year 1991, the six major plants, of which five were in the public sector, produced 10 million tons. The rest of India's Steel production, 4.7 million tons, came from 180 small plants, almost all of which were in the private sector. India's Steel production more than doubled during the 1980s but still did not meet the demand in the mid - 1990s. The government was seeking private - sector investment in new steel plants. Production was projected to increase substantially, As a result, plants set up a 1 million ton steel plant and three pig-iron plants totaling 6000,000 tons capacity in West Bengal, with Chinese technical assistance and financial investment. The commissioning of Tata Iron \& Steel Company's production unit in Jamshedpur, Bihar in 1911-12 heralded the beginning of the modern steel industry in India. At the time of Independence and the commencement of five year plans, the Government of India decided to set up four integrated steel plants at Rourkela, Durgapur, Bhilai and Bokaro. The Bokaro plant was commissioned in 1972. The most recent addition is a 3 Mt integrated steel plant with modern technology in Visakhapatnam. Steel Authority of India (SAIL) accounts for over 40 percent of India's crude steel production. SAIL comprises of nine plants, including five integrated and four special steel plants. Of these, one was nationalized and two were acquired, several were set up in collaboration with foreign companies. SAIL also owns mines and subsidiary companies

\section{PERFORMANCE DIVERGENCE AND FINANCIAL DISTRESS}

The survival of a firm depends on its performance in the past years. A firm having a balanced capital structure with good resource utilization efficiency will survive and perform well. The financial performance should be closely monitored to avoid industrial sickness and to ensure consistent growth. An objective forecast of the unit's financial 
performance can avoid a shutdown. An analysis of the financial statements for the required period will aid predicting industrial sickness that could crop up in future. The technique of ratio analysis is capable of diagnosing sickness in the firms and determines the factors that lead to financial distress and failure of the companies.

The period 2000-2010 had different phases of crisis, high growth and slow down. The steel industry, in particular has fallen a prey to these unfavorable economic conditions, resulting in unhealthy performance. In spite of the situation, some firms have performed well, proving that performance differences among firms depend largely on the firms' unique characteristics or internal factors. This chapter analyses the real factors that account for the difference in firms' performance and the possibility of the firms facing financial distress.

Dr. Edward. I. Altman's multiple discriminant analysis models has been employed to identify the causes of deteriorating performance of the firms in the steel industry, so that steps can be taken to shape business strategies to avert sickness. From an initial list of financial ratios, the final model evolved by Altman comprising of five ratios, together with their respective weightage has been worked out as a single index, namely ' $Z$ ' score.

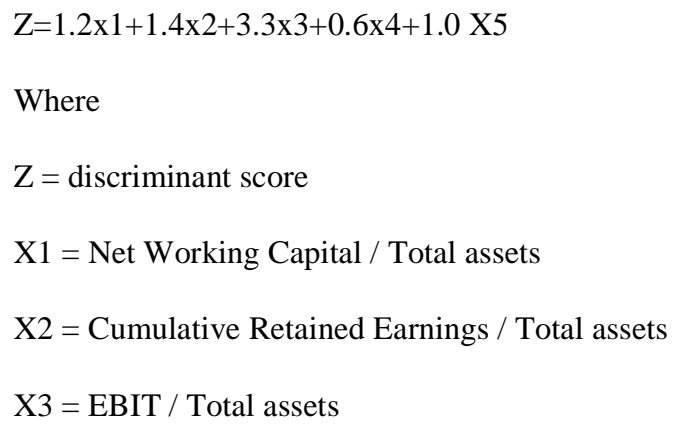

$\mathrm{X} 2=$ mentions the reserves and surpluses built over a period of years for reinvestment purposes or it may show the losses of a firm over its entire life. New companies with low reserves are more likely to become sick than the established firms with huge reserves.

$\mathrm{X} 3$ = reveals profitability. It is a measure to evaluate how effectively the assets of a firm are being employed. The profits are free from the effect of interest and tax. If the ratio exceeds the average interest rate, the company borrowings may be considered as effective.

X4 = indicates the debt service capacity of a company. These measures show, by how much, the firms' assets can decline in value (as measured by market value), before the liabilities exceed the assets and the firms become insolvent.

$\mathrm{X} 5$ = Compares the effective use of assets in generating and improving sales. A firm that can turn over its stocks number of times in a year over its assets is considered healthy.

\section{Prediction of Financial Distress - Altman's Model}

According to Altman, firms with ' $Z$ ' score of 1.81 or lower have a high probability of becoming bankrupt in due 
course of time, firms with scores above 2.99 have virtually no probability of becoming bankrupt. They are considered to be in the region of "No threat". Firms with a score above 1.81 but below 3.00 are in the "gray areas". These firms could be financially distressed.

The analysis has been done based on the trend of ' $Z$ ' score values for small, medium and large size firms, and less profitable and more profitable firms. Based on the mean discriminant score, the companies can be classified into three categories, namely: "probability of bankruptcy" "financially distressed" and "No probability of bankruptcy".

Table 2: Performance Analysis of Small Size Firms-Discriminant Score

\begin{tabular}{|c|c|c|c|c|c|c|c|c|c|c|c|c|c|c|}
\hline \multirow{2}{*}{ Companies } & \multicolumn{11}{|c|}{ Year } & \multirow{2}{*}{ Mean } & \multirow{2}{*}{ S.D } & \multirow{2}{*}{ C.V } \\
\hline & 2000 & 2001 & 2002 & 2003 & 2004 & 2005 & 2006 & 2007 & 2008 & 2009 & 2010 & & & \\
\hline & 1.77 & 3.59 & 4.63 & 4.37 & 2.84 & 4.17 & & 2.15 & & 1.78 & & & 1.08 & 32.36 \\
\hline & & & & & & & & & & & & & & \\
\hline & & - & \begin{tabular}{|l|}
- \\
\end{tabular} & & - & 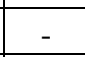 & 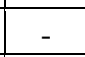 & \begin{tabular}{|l|}
- \\
\end{tabular} & 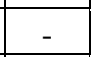 & - & 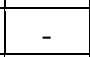 & - & 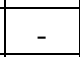 & - \\
\hline Gnogtri Jron \& Ste & 1.49 & 1.80 & 2.60 & 2.43 & 2.31 & 2.08 & 1.74 & 2.10 & 1.13 & 0.52 & 0.82 & 1.73 & 0.67 & 39.05 \\
\hline Garg Furnace Ltd. & 3.17 & 4.17 & 5.05 & 4.74 & 4.81 & 5.77 & 4.47 & 5.41 & 3.14 & 3.04 & 3.47 & 4.30 & 0.97 & 22.49 \\
\hline & 3.23 & 2.08 & 1.94 & -0.10 & 2.01 & 2.09 & 2.51 & 2.62 & 2.85 & 3.12 & 3.26 & 2.33 & 0.95 & 40.67 \\
\hline & 4.00 & 5.40 & 5.84 & 6.04 & 5.80 & 5.75 & 5.31 & 4.89 & 5.61 & 5.99 & & 5.25 & 0.92 & 17.53 \\
\hline Real Strips Ltd. & 1.00 & 1.63 & 1.78 & 1.67 & 1.78 & 2.04 & 2.26 & 1.63 & 1.60 & 1.01 & 1.56 & 1.63 & 0.37 & 22.98 \\
\hline Shivalik Bimetal Controls Ltd. & 2.41 & 1.71 & 1.69 & 1.52 & 1.45 & 1.67 & 1.79 & 1.86 & 2.25 & 1.85 & 2.30 & 1.86 & 0.32 & 17.21 \\
\hline Shri Bajrang Alloys Ltd. & 3.39 & 3.47 & 2.81 & 2.33 & 3.17 & 2.61 & 2.39 & 3.25 & 4.17 & 3.28 & 3.13 & 3.09 & 0.53 & 17.23 \\
\hline Sirhind Steel Ltd. & 3.85 & 6.02 & 8.84 & 8.12 & 9.56 & 4.52 & 3.75 & 3.51 & 3.00 & 3.75 & 3.84 & 5.34 & 2.39 & 44.77 \\
\hline
\end{tabular}

Source: computed *Market value not available as stocks, is not traded.

Table 3: Performance Analysis of Medium Size Firms-Discriminant Score

\begin{tabular}{|c|c|c|c|c|c|c|c|c|c|c|c|c|c|c|}
\hline \multirow{2}{*}{ Companies } & \multicolumn{11}{|c|}{ Year } & \multirow{2}{*}{ Mean } & \multirow{2}{*}{ S.D } & \multirow{2}{*}{ C.V } \\
\hline & 2000 & 2001 & 2002 & 2003 & 2004 & 2005 & 2006 & 2007 & 2008 & 2009 & 2010 & & & \\
\hline Bhuwalka Steel Inds. Ltd. & 2.40 & 2.12 & 2.94 & 3.03 & 3.10 & 2.85 & 2.28 & 2.70 & 2.47 & 1.97 & 2.26 & 2.56 & 0.39 & 15.20 \\
\hline Electrotherm (India) Ltd. & 1.74 & 1.61 & 1.43 & 1.30 & 1.13 & 0.95 & 0.75 & 1.33 & 1.33 & 0.72 & 0.68 & 1.18 & 0.36 & 30.70 \\
\hline \begin{tabular}{|l|} 
Ensa Steel Inds. Ltd. \\
\end{tabular} & 5.47 & 5.28 & 6.08 & 7.57 & 10.89 & 6.18 & 6.07 & 5.86 & 29.78 & 7.11 & 6.83 & 8.83 & 7.12 & 80.63 \\
\hline Kanishk Steel Inds. Ltd. & 2.28 & 2.67 & 3.09 & 2.81 & 3.72 & 5.36 & 2.67 & 4.88 & 5.28 & 2.41 & 2.49 & 3.42 & 1.19 & 34.85 \\
\hline Mahindra Ugine Steel Co. Ltd. & 1.52 & 1.60 & 1.68 & 1.25 & 1.88 & 4.49 & 4.51 & 2.43 & 1.75 & 0.93 & 1.41 & 2.13 & 1.23 & 57.72 \\
\hline Modern Steels Ltd. & 2.23 & 2.49 & 2.41 & 2.00 & 2.61 & 3.16 & 2.19 & 1.88 & 2.06 & 2.10 & 2.75 & 2.35 & 0.38 & 16.12 \\
\hline Pennar Industries Ltd. & 1.25 & 0.15 & 0.01 & 0.95 & 1.19 & 1.30 & 1.93 & 1.34 & 2.87 & 2.52 & 2.84 & 1.49 & 0.97 & 65.47 \\
\hline Rathi Steel \& Power Ltd. & 4.20 & 3.32 & 3.25 & 2.91 & 2.37 & 2.39 & 1.42 & 1.39 & 1.22 & 1.03 & 1.24 & 2.25 & 1.07 & 47.53 \\
\hline Ruchi Strips \& Alloys Ltd. & 1.67 & 1.48 & 1.67 & 1.69 & 1.99 & 2.06 & 1.87 & 2.07 & 2.04 & 1.00 & 1.69 & 1.75 & 0.32 & 18.16 \\
\hline Shah Alloys Ltd. & 1.18 & 1.21 & 1.22 & 1.53 & 1.76 & 1.88 & 1.67 & 1.62 & 0.77 & 0.78 & 1.15 & 1.34 & 0.38 & 28.12 \\
\hline Stelco Strips Ltd. & 1.91 & 2.15 & 1.93 & 1.51 & 1.81 & 2.17 & 1.33 & 1.39 & 1.91 & 1.58 & 1.98 & 1.79 & 0.29 & 16.30 \\
\hline Surana Industries Ltd. & 1.63 & 1.56 & 1.19 & 1.25 & 1.27 & 1.13 & 1.65 & 1.66 & 1.38 & 0.96 & 1.61 & 1.39 & 0.25 & 17.64 \\
\hline Tayo Rolls Ltd. & 2.65 & 2.39 & 2.76 & 3.78 & 4.56 & 2.60 & 2.85 & 2.80 & 5.25 & 1.22 & 1.27 & 2.92 & 1.22 & 41.95 \\
\hline Tulsyan N E C Ltd. & 1.55 & 2.00 & 1.79 & 1.57 & 1.56 & 1.41 & 1.35 & 1.36 & 1.57 & 1.42 & 1.34 & 1.54 & 0.20 & 13.28 \\
\hline Vardhman Industries Ltd. & 1.46 & 1.83 & 1.70 & 1.97 & 2.35 & 2.24 & 1.73 & 1.49 & 2.52 & 2.56 & 2.58 & 2.04 & 0.43 & 20.99 \\
\hline
\end{tabular}

It has been noticed from the Table 7 that, the discriminant score classify the companies in to three categories: "probability of bankruptcy", "Companies in financial distress" and "No threat Companies" Based on the mean discriminant”, score the probability of bankrupt companies are : Electrotherm (india) Ltd, penner Industries Limited, Ruche strips \& Alloys Ltd., Shah Alloys Limited, Stelco Strips Limited, Surana Industries Limited and Tulsyan NEC Ltd., 
with mean discriminant scores of 1.18, 1.49,1.75,1.34,1.79,1.39 and 1.54, respectively.

Companies in financial distress have been identified as: Bhuwalka Steel Industries Limited, Mahindra ugine Steel Co. Limited, Modern Steels Limited, Rathi Steel \& power Limited, Tayo Rolls Limited and Vardhman Industries Limited and their mean discriminant scores are 2.56.2.13, 2.35, 2.25, 2.92, and 2.04, respectively. Only two companies have been found under "No threat of bankruptcy". They are: Ensa Steel Industries Ltd. and Kanishik Steel Industries Limited, with mean discriminant scores of 8.83 and 3.42, respectively. Among the medium sized firms, the Ensa Steel Industries Limited has revealed the highest C.V of 80.63 percent with S.D of 7.12, which conveys a high volatility in the discriminant score, during the study period.

Table 4: Performance Analysis of Large Size Firms-Discriminant Score

\begin{tabular}{|c|c|c|c|c|c|c|c|c|c|c|c|c|c|c|}
\hline \multirow{2}{*}{ Companies } & \multicolumn{11}{|c|}{ Year } & \multirow{2}{*}{ Mean } & \multirow{2}{*}{ S.D } & \multirow{2}{*}{ C.V } \\
\hline & 2000 & 2001 & 2002 & 2003 & 2004 & 2005 & 2006 & 2007 & 2008 & 2009 & 2010 & & & \\
\hline Bhushan Steel Ltd. & 1.29 & 1.27 & 1.23 & 1.05 & 1.23 & 1.34 & 1.04 & 1.04 & 0.89 & 0.68 & 0.93 & 1.09 & 0.20 & 18.63 \\
\hline J S W Ispat Steel Ltd. & 0.27 & 0.23 & 0.07 & 0.40 & 0.43 & 0.99 & 0.09 & 0.49 & 1.24 & 0.24 & 0.72 & 0.47 & 0.37 & 79.50 \\
\hline Kalyani Steels Ltd. & 1.26 & 1.78 & 1.59 & 1.79 & 2.51 & 2.96 & 9.10 & 15.50 & 7.53 & 1.94 & 3.29 & 4.48 & 4.46 & 99.73 \\
\hline Monnet Ispat\& Energy Ltd. & 1.87 & 1.59 & 1.23 & 1.63 & 1.47 & 2.21 & 1.69 & 1.53 & 3.00 & 1.48 & 2.04 & 1.79 & 0.49 & 27.06 \\
\hline Mukand Ltd. & 1.32 & 1.17 & 0.82 & 0.57 & 0.99 & 1.67 & 1.73 & 1.74 & 1.53 & 0.97 & 1.53 & 1.28 & 0.40 & 31.43 \\
\hline National Steel \& Agro Inds. Ltd. & 1.62 & 1.81 & 1.73 & 1.78 & 1.60 & 1.47 & 1.49 & 1.55 & 1.83 & 1.22 & 2.31 & 1.68 & 0.28 & 16.49 \\
\hline Steel Authority Of India Ltd. & 0.75 & 0.74 & 0.40 & 0.82 & 2.71 & 4.81 & 4.88 & 7.47 & 25.26 & 4.71 & 5.51 & 5.28 & 7.04 & 133.45 \\
\hline Sujana Metal Products Ltd. & 1.08 & 1.23 & 0.95 & 1.26 & 1.68 & 2.03 & 3.63 & 2.11 & 1.31 & 1.21 & 1.38 & 1.62 & 0.76 & 46.87 \\
\hline Sunflag Iron \& Steel Co. Ltd. & 1.43 & 1.91 & 1.77 & 1.60 & 2.21 & 2.72 & 2.27 & 1.84 & 3.13 & 1.98 & 3.03 & 2.17 & 0.57 & 26.15 \\
\hline Tata Steel Ltd. & 1.39 & 1.49 & 1.32 & 1.48 & 3.02 & 5.95 & 6.27 & 3.17 & 2.84 & 1.32 & 2.54 & 2.80 & 1.79 & 63.91 \\
\hline Uttam Galva Steels Ltd. & 0.74 & 0.79 & 0.79 & 1.03 & 1.00 & 1.43 & 1.11 & 0.99 & 1.32 & 0.91 & 1.47 & 1.05 & 0.26 & 24.26 \\
\hline
\end{tabular}

Source: computed

It is highlighted from the Table7.13 that the firms, based on the mean discriminant score, are classified into three categories namely: "probability of bankruptcy" "financial distress" and "probability of no bankruptcy". Based on the mean discriminant score, the probable bankrupt companies are: Bhushan Steel Limited, JSW Ispat Steel Limited, Monnet Ispat\& Energy Limited, Mukund Limited, National Steel \& Agro Industries Limited, Sujana Metal products Limited and Uttam Galva steels Limited with mean discriminant scores of 1.09, 0.47, 1.79, 1.28, 1.68, 1.62, and 1.05, respectively.

Only two companies have been categorized as financially distressed and fall under "grey area". They are: Sun Flag Iron and Steel Co. Ltd. and Tata Steel Limited with mean discriminant scores of 2.17 and 2.80 respectively. There are two companies under "No probability of bankruptcy". They are Kalyani Steels Limited and Steel Authority of India Limited with discriminant scores of 4.48 and 5.28, respectively. Among larger sized firms, the Steel Authority of India Limited has been inconsistent with a discriminant score with the C.V of 133.45 percent and S.D of 5.28, during the study period.

The present has attempted to identify the real factors that account for the differences in the firms' performance and the possibility of the firms facing financial distress. The fourth objective of the study has used Edward I Altman's Multiple Discriminant model, to identify the causes of deteriorating performance of the firms and to take suitable measures, to avert sickness and inefficiency. Altman has developed a single index " $Z$ " score, after allocating weightage to five strategic ratios selected from the list of financial ratios. According to Altman, a firm with a ' $Z$ ' score of 1.81 or less has a high probability become bankrupt. The 'Z'score of 1.81 to 2.99 places the firms in 'grey' area and ' $Z$ ' score above 
2.99 makes the firm immune to bankruptcy.

\section{FINDINGS}

Out of 11 small size companies, three companies belong to 'No threat area', 2 companies have been found in the 'grey' area and for six companies, and there is a threat of financial distress.

Out of 15 companies, 6 companies do not face any threat of sickness while 7 companies are found to be in 'grey' area and only 2 companies are expected to face the risk of financial distress. In general, the possibility of financial sickness is remote for medium size companies.

Out of 11 large size companies, 2 companies have no risk of financial sickness, while 7 companies have been in 'grey' area. Only 2 companies have an element of risk of financial distress to face. In general, the portion of companies in 'grey' area is more when compared to other groups.

For the steel industry in general, out of 37 selected companies, 11 companies do not face any threat of financial distress in the future, while 16 companies are in 'grey' area and 10 companies have the challenge of facing the financial distress in the future is based on the results of the study. The results, based on the study are in consonance with the results of H. Chandra and V. Selvaraj (2013).

Among the five variables contributing to the ' $\mathrm{Z}$ ' score to assess the possibility of financial distress in future, namely, Net working capital to total assets, Cumulative retained earnings to total assets, EBIT to total assets, Market value of equity to Book value of debt and Sales to Total assets, the variable namely, cumulative retained earnings to total assets has been the main cause for the low level of ' $Z$ ' score. The companies which are found to be in financial distress do not have sufficient accumulated profits or retained earnings to plough back during the times of need.

It has been found that the private sector companies have a significant dominance in the Indian steel industry while compared to the public sector.

The study reveals that even if the firms are profitable, a few companies have moved to the 'grey' area and the 'area of threat'. Hence, the general hypothesis that all profitable firms are free from financial distress is thus not accepted. The steel sector in India has marked a good financial performance. In general, the leverage has been optimum, but the reinvestment rate has been insignificant, which, if improved will enhance the present financial performance and sustainable growth rate, thereby will create a greater shareholder value and better share in the global market.

\section{CONCLUSIONS}

Altman's model would support to identify the performance differences in the companies. The areas of strength and weakness may be identified with the help of these models, so that the companies can concentrate and take suitable action to remedy the situation and improve the financial health. The firms should make an introspective of their financial position systematically, applying the Altman's bankruptcy model. The model enables the firms to identify the performance difference in the variables of the model to take vital decisions and actions to strengthen the situation. This model is a barometer to have a quick check of financial health. The ' $Z$ ' score may be used as a gauge of relative financial health rather than as a predictor of sickness. 


\section{REFERENCES}

1. Abd.el. Mataal, M.H.B. "Working Capital: Its Role in the Short Term Liquidity Policy of Industrial Concerns", Accounting Research, Vol.9, p.226, 1958. Donnel,O.and Goldberg, op.cit., p.55,1964.

2. Chakraborty, S.K., et al., 'New Perspectives in Management Accounting', Macmillan, New Delhi, pp.110-125,1979.

3. Smith, K.V., An overview of working capital management in Management of working capital, Working Capital Management: A Reader, New York: West Publishing Company, pp.3-20,1974.

4. Edward I. Altman,RobertC.Haldeman and P.Narayanan, "Zeta Analysis: A New Model to identify bankruptcy rikcorporations",Journal of Banking and Finance,pp.29-54,June 1977.

5. Bhattacharys, S.K. Ragavachari, M. "Determinants of Effective Working Capital Management: A Discriminant analysis approach”, Working Paper No: 151, Indian Institute of Management, Ahamedabad, March 1977.

6. Richard Taffler and Howard Tisshan, "Going, Going, Gone - four factors which predict corporate failure”, Accountancy, March 1977,pp 50-54

7. Ramamoorthy, V.E., “Working Capital Management”, Institute of Financial Management and Research, Madras, 1978.

8. Kulshreshta,N.K.. “Corporate Liquidity - X rayed”, The Management Accountant, Vol.15, No.8, pp.331-334, August.

9. Robert C. Higgins, “Sustainable Growth Rate under Inflation,” Financial Managemetn, Autumn 1981, pp 36-40

10. Bhabotosh Banerjee, "Corporate Liquidity and Profitability in India”, Research

11. Krown, A.J. et al. 'Basic Financial Management', New Delhi: Prentice Hall of India Pvt. Ltd., p.131,1985.

12. John J. Clerk, Margaret T. clark, and Andrew G. Versilli, “Strategic planning \& Sustainable Growth", Columbia Journal of world Business, Fall 1985, P 47-51.

13. Chandrasekaran, N. "Market Structure and Financial Performance". Unpublished d3ctoral dissertations, University of Madras, 1989.

14. Jane, M.Cote and Claire KammLatham, The Merchandising Ratio: A comprehensive measure of working capital strategy; Issues in Accounting Education, May 1999, pp.55-67,1999.15.

15. Sinha, Sidharth, Inter-Industry variations in Capital structure, Economic and Political Weekly, August 1993.

16. Klein Daniel P and Brian Belt, "Sustainable Growth and choice of financing; A test of the pecking order Hypothesis", Review of Financial Economies, Fall 93/spring 94, Vol 3, Issue 1/2, P.141-154.

17. Harlan, D.P., Majorie,B.P and Gunglichan, "Sustainable Growth Rate of Firms in Financial Distress", Journal of Economics and Finance, Vol.19, No:2, pp.147-151, 1995.

18. George Schilling and Associates, “Working Capital Role in Maintationg Corporate Liquidity”, TMA Journal Section: Outlook, September / October 1996.

19. Vijaya Kumar, A. “Assessment of Corporate Liquidity - A discriminant Analysis Approach”, The Management Accountant, pp.589-591, August 1996.

20. M. Beaumont Smith and E.Begemann, "Measuring Association between Working Capital and Return on Investment", South African Journal of Business Management; March 01, vol:28, pp.81-92,1997.

21. Bhairav, H.D., "Assesment of Liquidity - Inter Firm Comparison”, UdyogPrragati, October - December 1997.

22. Prof. AmitMallick and Debasish Sur, “Working capital and profitability: a case study in interrelation”, The Management Accountant, pp.805-809, November 1998.

23. Hyun-Han Shin and Luc Soenen. Efficiency of working capital management and corporate profitability, Financial Practice and Education, Fall, Winter 1998, pp.68-79, 1998.

24. Burger, J.H., and Hamman, W.D., "The Relationship between the Accounting Sustainable Growth Rate and the Cash Flow Sustainable Growth Rate”, South African Journal of Business Managemant, Vol:30, Issue\$,December 1999.

25. Gary W.Emery, "Sustainable Growth for credit Analysis”, Business credit, P. 35-39, February 2000.

26. George W.Gallinger: "A framework for financial statement analysis Part 1; Return-on Assets Performance”, Business Credit, 
Feb. 2000. Vol.102, Issue 2, pp.103-115, Feb.2000.

27. Gopal Krishna Swami L, “A Forecasting model for Sustainable Corporate Growth”, The Management Accountant, August 2000, pp 579-584

28. KiranSankar Chakraborty, "Anatomy of overtrading in corporate performance with special reference to Indian Panorama", Finance India, Vol. XIV, No.4, December 2000, pp 1247 -1249.

29. MahammadRafique Islam, (University of Bangladesh), "Profitability of fertilizer industry in Bangladesh", The Management Accountant, pp.338-345, May 2000.

30. R.K.Sahu, "Analysis of Corporate Profitability -a multivatiate approach" $<$ The Managemetn accountant, pp.571-577, August,2000.

31. Debasish Sur, "Liquidity management: an overview of four companies in Indian power sector", The Management Accountant, pp. 407-412, June 2001.

32. Ralph I.Udegbunam, "Financial Distress and Performance Differences among Commercial Banks in Nigeria: A Multivariate Ratio Analysis", Finance India, vol.XV,No.2, pp.551-556, June 2001.

33. Satish Chandra Varshney, "Trade credit and Company Liquidity”, The Management Accountant, October 2001, pp.738-756, 2001

34. Michael C. Pickett, "Harley -Davidson, inc -Sustainable Growth Rate Modelling Analysis", Academic Exchange - Extra, February 2002.

35. Sankaran, K. "Financial Performance Evaluation of Pharmaceutical Companies in India", Finance India, Vol.XVI, No.3 pp.1059-161, September, 2002.

36. ManojAnand and Gupta C.P,. "Marketing Capital Performance of Corporate Business India: An Emprical Survey foe the year 2000-2001”, Management and Accounting Research, January - June, 2003.

37. Baradia S.C., "Liquidity Management: A Case Study of Steel Authority of India Ltd.”, The Management Accountant, pp.463467, June 2004.

38. Hamsalakshmi and Manickam, "Financial Performance Analysis of Selected Software Companies", Finance India, Vol.XIX, No.3., pp.915-935, September, 2004.

39. Narware P. C., “Working Capital and profitability - An empirical analysis”, The Management Accountant, June 2004, PP 491-495.

40. AdolphusJ.Toby, "Empirical Survey of Corporate Liquidity Management practices of Nigerian-Quoted manufacturing enterprises”, Journal of Financial Management and Analysis, 18(2): 2005: P.41-56.

41. Bob Ebberson, "Matching Growth, Financial Resources is a balancing Act, "The New Hamshire, Small Business Development centre, Website, September 2005.

42. Encyclopedia of small Business, "Sustainable Growth", Copy right 2005 - Thomson Gale, a part of the Thomson Corporation.

43. RekhaSampath and AjitKambil, "Sustainable Growth: Is there Room to Grow?", Deloitte Research, A Deloitte Research viewpoint, November 2005, 6 pages.

44. Amarjit Gill, Nahum Biger, Neil Mathur, "The Relationship between working capital Management and Profitability: Evidence from the UntitedStates”, Business and Economics Journal, 2010,BEJ-10, pp:1-9

45. PadmajaManoharan, "Analysis of liquidity of selected Indian manufacturing companies”, May 2010.

46. Rajesh.M, Ramana Reddy N.R.V, “An Empirical study on Financial Distress”, Journal of Accounting and Finance, Vol: 24, No:2, April-September, 2010, pp 43-50.

47. NasrollahAmouzesh, Zahra Moeinfar, Zahra Mousavi, "Sustainable growth Rate and Firm performance: Evidence for Iran Stock Exchange", International Journal of Business and Social Science, Vol 2, no 23 (special issue - Dec 2011)

48. Fonseka M.M, Constantino Garcia Ranos, Gao-liangTian, "The most appropriate Sustainable Growth Rate model for managers and researchers", The Journal of Applied Business Research, Vol 28, No 3, May/June 2012 
49. U.Shaji and C.Ganesan, "Financial Performance of pharmaceutical companies", "Namex International Journal of Management Research Vol.2 Issue no: 1.

50. H.Chandra and V.Selvaraj, "Financial Analysis of selected steel companies in India", "smart journal business management studies" Vol.3 Issue no: 1

51. A.Dharmaraj and Dr.N.Kathirvel, "Financial eprformance of selected Indian automobiles", "global research analysis Vol.2 ISSN: $2277-8160$

52. P. Rajangam and V.Selvaraj, "Financial health of west coast paper Itd", "Primax International Journal Commerce And Management Research”, Vol.1 Issue no: 1 April-June, page 151.

53. Sarbapriya Ray, "Financial soundness of Indian Manufacturing Industry”, "Journal of Economic Philosophy”, Vol.2 June, page 88 .

54. Sivakumar, "Financial efficiency of steel industry in India”, "International Journal of accounting and financial management research, ISSN - 2249:6882, Vol.3. 